\title{
THE IMPACT OF A RAPID SEQUENCE INTUBATION ON ARTERIAL BLOOD GASES DURING THE PREOXYGENATION PHASE PERFORMED IN A HOSPITAL EMERGENCY DEPARTMENT
}

\author{
Suzer Ergun Neslihan, ${ }^{1}$ Sirkeci Ozgur, ${ }^{2}$ Sirkeci Erkus Emel ${ }^{3}$ \\ ${ }^{1}$ Kocaeli Gebze Fatih State Hospital Emergenceny Service, Kocaeli, Turkey \\ ${ }^{2}$ Suleyman Demirel University Faculty of Medicine \\ İnternal Medicine Gastroenterology Department, Isparta, Turkey \\ ${ }^{3}$ Near East University Faculty of Medicine Emergency Department, Girne, Cyprus
}

Primljen/Received 27. 04. 2021. god.

Abstract: Aim: During rapid sequence intubation (RSI), the $\mathrm{O}_{2}$ reserve limits the intubation duration. The study objective was to examine the impact of RSI on arterial blood gases (ABG) during the preoxygenation phase.

Methods: This open, prospective clinical study examined samples of patients who had endotracheal intubation (ETI) as RSI between March 2014 and September 2014 in our emergency department. The variations in $\mathrm{ABG} \mathrm{PaO}_{2}$ and $\mathrm{PaCO}_{2}$ before and after preoxygenation and after intubation were examined and compared with demographic and clinical variables.

Results: The study included 67 patients (46 male, 21 female) with a mean age of 69.9 years. SBP, DBP, and MABP decreased, while pulse rate and $\mathrm{SpO}_{2}$ increased. No difference was observed between $\mathrm{PaO}_{2}$ values and demographic and clinical variables; however, a statistically significant relationship was found between the difference $(\Delta)$ between $\mathrm{PaO}_{2}$ values measured after endotracheal tracheal intubation (ETI) and after preoxygenation and the $\mathrm{ABG} \mathrm{SpO}_{2}$ and the $\mathrm{SpO}_{2}$ classification before preoxygenation.

Conclusion: The relationship between $\mathrm{SpO}_{2}$ and its classification following ETI and increased ABG $\mathrm{SpO}_{2}$ was statistically significant. Our real-life study emphasises that deciding on intubation without desaturating patients could have positive effects on intubation success. Regardless, increasing $\mathrm{SpO}_{2}$ prior to ETI will contribute positively to the $\mathrm{O}_{2}$ reserve by the end of ETI.

The $\Delta \mathrm{PaO}_{2}$, before and after preoxygenation, was not affected by age; gender; body mass index (BMI) and its classification; GCSS; vital signs and ABG find-
Prihvaćen/Accepted 03. 08. 2021. god.

ings gathered before preoxygenation; respiration rate (RR) during preoxygenation; preoxygenation duration; oral air passage usage or air leakage.

Keywords: Rapid sequence intubation, preoxygenation, emergency ward.

\section{INTRODUCTION}

Rapid sequence intubation (RSI) is the standard airway management practice in the emergency department (ED) because it provides rapid sedation and paralysis. Clinical treatment requires quick recognition of respiratory failure since a decision for endotracheal intubation (ETI) may be difficult for emergency physicians, and the ETI must be performed fast when indicated.

Preoxygenation generates a potential $\mathrm{O}_{2}$ reserve by allowing an exchange of nitrogen and oxygen in the alveolar area during a few minutes of apnea (1). When an ETI is considered, preoxygenation must be started in the shortest possible timeframe. In RSI, all patients, including those without manifest hypoxia, are preoxygenated. Preoxygenation provides a security buffer between hypoventilation and apnea and prolongs the safe apnea duration(the period required to maintain peripheral capillary oxygen saturation $\left(\mathrm{SpO}_{2}\right)$ between $88-90 \%$ until a permanent airway is ensured). If preoxygenation is not performed, the $\mathrm{SpO}_{2}$ drops to very critical levels $(<70 \%)$ within minutes $(1,2,3)$.

Although the ideal preoxygenation duration is debatable, the general advice is to deliver $100 \% \mathrm{O}_{2}$ at 15 $\mathrm{L} / \mathrm{min}$ for 3-5 minutes with a non-backflow respiration mask. Consequently, 8 minutes is provided for desatu- 
ration. This period is shortened for critical patients and patients with advanced metabolic disturbances $(1,2,3)$.

There are different ways to perform preoxygenation. In patients with spontaneous respiration $\mathrm{O}_{2}$ support can be provided with an oral mask or nasal catheter and then requesting the patients to inspire deeply (4). In patients with insufficient respiration and variable consciousness levels, preoxygenation can be applied with a non-backflow respiration balloon mask. Another recently welcomed preoxygenation method is the use of non-invasive mechanical ventilation. Some publications indicate a higher success rate using non-invasive mechanical ventilation with elective hypoxia cases $(5,6)$.

In this study, the effects of the preoxygenation phase parameters (such as breath count and preoxygenation duration) on arterial blood gas (ABG) were examined in ED patients who underwent RSI. The primary efficacy endpoint was an increase in the ABG partial oxygen pressure $\left(\mathrm{PaO}_{2}\right)$. The secondary efficacy endpoint was a decrease in the $\mathrm{ABG}$ partial carbon dioxide pressure $\left(\mathrm{PaCO}_{2}\right)$.

\section{MATERIAL AND METHODS}

This study was an open, prospective clinical study conducted on patients who underwent ETI in the adult ED between March 1st, 2014, and September 30th, 2014 in Istanbul Education Research Hospital. Approval was granted by the hospital ethics committee (21.02.2014/433) and the research budget committee (28.01.2014/852).

During the study, ETI was performed on 273 patients; 144 (52.7\%) underwent RSI. Of the latter, 77 patients $(53.5 \%)$ were excluded for the following reasons: cardiac arrest during ETI (49 patients, 34\%), age $<18$ years (5 patients, 3.5\%), ABG measurement error (missing data, measurement failure, inappropriate sample) (13 patients, 9\%), consent not given by the family (10 patients, 7\%). In total, 67 patients (46 men and 21 women) were included in the final analysis.

Preoxygenation was performed on patients in a supine position. The patients were provided with $100 \% \mathrm{O}_{2}$ support with a balloon mask with a reservoir by a one-handed C-E technique according to the 2010 American Heart Association Resuscitation Guideline. The goal was to provide $8-10$ breaths/minute as per 1 breath in 6-8 seconds and to support spontaneous respiration. The patients were monitored for $\mathrm{SpO}_{2}$ during breath giving. The $\mathrm{ABG}$ measurement was used to assess the sufficiency of $\mathrm{O}_{2}$ provision sufficiency. For ABG measurement $2 \mathrm{ml}$ of arterial blood was obtained from the radial or femoral artery while respecting the asepsis-antisepsis rules at the end of preoxygenation and just before drug administration, without delaying the ETI. The blood was drawn into heparinized injector syringes (BD Preset \& BD A-Line, Becton, Dickinson and Company, Belliver Industrial Estate, Plymouth, UK) and analyzed in an ABG device (RAPID Lab 1200 Systems, Siemens Healthcare Diagnostics Inc., NewYork, USA).

Descriptive analyses were conducted for all data and study parameters (SP) listed below. The differences between $\mathrm{ABG} \mathrm{PaO}_{2}\left(\triangle \mathrm{PaO}_{2}\right)$ andABG $\mathrm{PaCO}_{2}$ $\left(\triangle \mathrm{PaCO}_{2}\right)$, both before and after preoxygenation, were calculated. The second $\Delta \mathrm{PaO}_{2}$ (i.e. the $\Delta \mathrm{PaO}_{2}$ between the end of preoxygenation [second measurement] and following the ETI [third measurement]) and the similarly measured second $\triangle \mathrm{PaCO}_{2}$ between the end of preoxygenation and after ETI were then calculated.

The correlations were investigated between the following SP and the $\triangle \mathrm{PaO}_{2}$ and $\Delta \mathrm{PaCO}_{2}$; and the second $\triangle \mathrm{PaO}_{2}$ and second $\triangle \mathrm{PaCO}_{2}$ :

- Age

- Gender

- BMI and its classification

- GCSS

- Parameters before preoxygenation:

- Mean Arterial Blood Pressure (MABP)

- $\mathrm{SpO}_{2}$ and its classification

- $\mathrm{ABG} \mathrm{SpO}_{2}$

- Respiration rate $(\mathrm{RR})$

- Preoxygenation parameters:

- Provided breath count

- Preoxygenation duration

- Airway usage

- Air escape

SPSS 15.0 for Windows was used for statistical analysis. In descriptive statistics, we used numbers and percentages for categorical variables, whereas using the mean, standard deviation, and minimum and maximum values for numerical variables. When a normal distribution could not be met, comparisons of two independent groups were performed using the Mann Whitney U test. The Kruskal Wallis test was applied for comparisons of multiple groups. Chi-square analysis was used to test the independent proportionalities of categorical variables between groups. A bivariate normal model for correlation detection was used as correlation $\mathrm{pH} 0=0$, alpha error probability 0.05 , and correlation $\mathrm{pH} 1=0.3$. The statistical significance threshold was $\mathrm{p}<0.05$.

\section{RESULTS}

The patients' demographic and clinical characteristics are shown in Table 1. The vital signs before and after preoxygenation, according to the Joint National Committee (JNC)-8, classification are shown in Table 2. 
Table 1. Second $\triangle \mathrm{PaO}_{2}$ and its relationship with $\mathrm{SP}-2$

\begin{tabular}{|c|c|c|c|}
\hline & \multicolumn{3}{|c|}{$\Delta \mathrm{PaO}_{2} 3^{\text {rd }}-2^{\text {nd }}$ measurement } \\
\hline & & Mean \pm SD & $\mathrm{p}$ \\
\hline \multirow[t]{2}{*}{ Gender } & Male & $159.3 \pm 124.7$ & \multirow[t]{2}{*}{0.111} \\
\hline & Female & $99.0 \pm 76.4$ & \\
\hline \multirow[t]{2}{*}{ Airway usage } & Yes & $127.9 \pm 102.5$ & \multirow[t]{2}{*}{0.671} \\
\hline & No & $148.3 \pm 122.4$ & \\
\hline \multirow[t]{2}{*}{ Air Escape } & No & $148.7 \pm 118.5$ & \multirow[t]{2}{*}{0.250} \\
\hline & Yes & $98.3 \pm 85.6$ & \\
\hline \multirow[t]{3}{*}{ BMI classification } & Normal & $153.5 \pm 127.4$ & \multirow[t]{3}{*}{0.855} \\
\hline & Slightly overweight & $128.4 \pm 99.7$ & \\
\hline & Obese & $134.2 \pm 117.9$ & \\
\hline \multirow[t]{2}{*}{$\mathrm{SpO}_{2}$ classification before preoxygenation } & $<90$ & $98.6 \pm 95.4$ & \multirow[t]{2}{*}{0.008} \\
\hline & 90 and $>90$ & $174.3 \pm 119.0$ & \\
\hline \multirow[t]{5}{*}{ Induction Agent } & Midazolam & $152.5 \pm 123.4$ & \multirow[t]{5}{*}{0.780} \\
\hline & Ketamine & $104.7 \pm 80.1$ & \\
\hline & Thiopental & $127.1 \pm 97.5$ & \\
\hline & Propofol & $64.8 \pm 45.0$ & \\
\hline & Etomidate & 95.1 & \\
\hline \multirow[t]{2}{*}{ Paralyzing Agent } & Vecuronium & $143.5 \pm 118.2$ & \multirow[t]{2}{*}{0.845} \\
\hline & Rocuronium & $129.7 \pm 104.7$ & \\
\hline
\end{tabular}

Table 2. The relationship of second $\triangle \mathrm{PaO}_{2}$ with $\mathrm{SP}$

\begin{tabular}{|c|c|c|c|c|}
\hline & & Rho/Value & Mean \pm SD & $\mathbf{P}$ \\
\hline \multicolumn{2}{|l|}{ Age } & 0.232 & & 0.059 \\
\hline \multirow{2}{*}{ Gender } & Male & & $159.3 \pm 124.7$ & \multirow{2}{*}{0.111} \\
\hline & Female & & $99.0 \pm 76.4$ & \\
\hline \multicolumn{2}{|l|}{ GCSS } & 0.074 & & 0.550 \\
\hline \multicolumn{2}{|l|}{ BMI } & -0.111 & & 0.372 \\
\hline \multirow{3}{*}{ BMI Classification } & Normal & & $153.5 \pm 127.4$ & \multirow{3}{*}{0.855} \\
\hline & Slightly overweight & & $128.4 \pm 99.7$ & \\
\hline & Obese & & $134.2 \pm 117.9$ & \\
\hline \multicolumn{2}{|l|}{ МАВP } & 0.193 & & 0.117 \\
\hline \multicolumn{2}{|l|}{$\mathrm{SpO}_{2}$} & 0.319 & & $\underline{0.009}$ \\
\hline \multirow{2}{*}{$\mathrm{SpO}_{2}$ classification } & $<90$ & & $98.6 \pm 95.4$ & \multirow{2}{*}{$\underline{\underline{0.008}}$} \\
\hline & $\geq 90$ & & $174.3 \pm 119.0$ & \\
\hline \multicolumn{2}{|l|}{$\mathrm{ABG} \mathrm{SpO}_{2}$} & 0.266 & & $\underline{0.030}$ \\
\hline \multicolumn{2}{|c|}{ Provided breath count } & -0.028 & & 0.825 \\
\hline \multicolumn{2}{|c|}{ Preoxygenation duration (sec) } & -0.156 & & 0.208 \\
\hline \multirow{2}{*}{ Airway Usage } & Yes & & $127.9 \pm 102.5$ & \multirow{2}{*}{0.671} \\
\hline & No & & $148.3 \pm 122.4$ & \\
\hline \multirow{2}{*}{ Air Escape } & Absent & & $148.7 \pm 118.5$ & \multirow{2}{*}{0.250} \\
\hline & Present & & $98.3 \pm 85.6$ & \\
\hline \multicolumn{2}{|l|}{ ETI duration } & 0,186 & & 0.132 \\
\hline \multirow{3}{*}{ Induction Agent } & Midazolam & & $152.5 \pm 123.4$ & \multirow{3}{*}{0.780} \\
\hline & Ketamine & & $104.7 \pm 80.1$ & \\
\hline & Thiopental & & $127.1 \pm 97.5$ & \\
\hline \multirow{2}{*}{ Paralyzing Agent } & Vecuronium & & $143.5 \pm 118.2$ & \multirow{2}{*}{0.845} \\
\hline & Rocuronium & & $129.7 \pm 104.7$ & \\
\hline
\end{tabular}


A) Before preoxygenation:

Mean $\mathrm{PaO}_{2}=80.2 \% \pm 49.8$ (range 26.8-257.1\%)

Mean $\mathrm{PaCO}_{2}=51.8 \% \pm 26.8$ (12.8-122.9\%).

The second $\Delta \mathrm{PaO}_{2}$ and its relationship with the general parameters are shown in Table 2,

B) Following the ETI:

Mean $\mathrm{PaO}_{2}=253.8 \% \pm 135.6$ (33.3-532.2\%)

Mean $\mathrm{PaCO}_{2}=46.1 \% \pm 20.7$ (17.9-115.7\%).

C) Mean $\Delta \mathrm{PaO}_{2}=33.3 \pm 59.8(-43.4-336.8)$

Mean $\Delta \mathrm{PaCO}_{2}=-1.2 \pm 9.7(-27.8-17)$

D) Mean second $\Delta \mathrm{PaO}_{2}=140.4 \pm 1147(-8.4-396.5)$

Mean second $\Delta \mathrm{PaCO}_{2}=-4.0 \pm 19.7$ (-55-91).

No statistically significant difference was noted between the effects of different SPon $\Delta \mathrm{PaO}_{2}(\mathrm{p}>0.05)$.

The $\Delta \mathrm{PaO}_{2}$ between the end of preoxygenation (second measurement) and that following ETI (third measurement) (i.e. the second $\Delta \mathrm{PaO}_{2}$ ) were compared with the SP in Table 2.

The relationships of the second $\Delta \mathrm{PaO}_{2}$ with the $\mathrm{SpO}_{2}$ and $\mathrm{SpO}_{2}$ classification before preoxygenation and preoxygenation $\mathrm{SpO}_{2}$ were statistically significant $(\mathrm{p}<0.05)$. A statistically significant positive correlation was found between the $\mathrm{SpO}_{2}$ before preoxygenation and the second $\Delta \mathrm{PaO}_{2}(\mathrm{p}=0.009)$. No other correlations were detected between the second $\Delta \mathrm{PaO}_{2}$ and the other SP. No statistically significant difference was noted between the other groups (Table 2 and Table 1 below).

Table 2 shows a statistically significantly higher mean of the second $\Delta \mathrm{PaO}_{2}$ for patients with $\mathrm{SpO}_{2} \geq 90$ than $\mathrm{SpO}_{2}<90$.

\section{DISCUSSION}

RSI studies typically involve induction and comparison of paralyzing techniques, RSI indications, and contraindications $(2,7)$. No study has yet assessed the preoxygenation efficiency in RSI. Our study calculated the authentic $\triangle \mathrm{PaO} 2$ values before and after preoxygenation in RSI, the relationship between these changes and the patients' demographic characteristics, vital signs, and preoxygenation parameters.

Chroniere et al. (8) found that voluntary hyperventilation before RSI did not cause a decrease in Pa$\mathrm{CO}_{2}$ after ETI. This supports our findings of no statistically significant relationship between preoxygenation parameters in RSI (i.e.the preoxygenation duration, breath count provided, ETI period, and $\triangle \mathrm{PaCO} 2$ before and after preoxygenation).

In our study, the most important factors regarding $\mathrm{O}_{2}$ level in patients who underwent RSI were their $\mathrm{SpO}_{2}$ prior to RSI and their $\mathrm{SpO}_{2}$ category. Nearly all the previous studies have shown that $\mathrm{O}_{2}$ support given prior to an ETI had to be continued during the ETI. This indicates that a higher $\mathrm{O}_{2}$ level prior to an ETI will lead to a lower and insignificant $\mathrm{SpO}_{2}$ decrease at the end of the ETI. Several factors influence the efficiency of $\mathrm{O}_{2}$ support given prior to an ETI. However, in our study, the efficiency of $\mathrm{O}_{2}$ support given prior to an ETI was directly correlated with the $\mathrm{O}_{2}$ amount provided before the ETI.

Therefore, the decision for intubation without desaturating patients could have positive effects on the intubation procedure. No matter how increased $\mathrm{SpO}_{2}$ is obtained prior to an ETI, the increase will contribute positively to the $\mathrm{O}_{2}$ reserve until the end of the ETI. The $\triangle \mathrm{PaO} 2$ before and after preoxygenation was not influenced by the SP. The relationships between $\mathrm{SpO}_{2}$ and its classification, following the ETI and the increase in $\mathrm{SpO}_{2}$, were found to be statistically significant.

A study by Davis et al. investigated the impact of hypoxia and hyperventilation on the outcome after RSI performed by paramedics on severely head-injured patients and pointed to the critical importance of correct RSI application for reduction in the mortality rate of these patients (4). Hyperventilation and severe hypoxia during paramedic RSI were associated with an increase in mortality.

Several previous studies $(9,10,11)$ support our findings of a positive effect of oxygenation on the peri-intubation $\mathrm{SpO}_{2}$ increase and better patient outcomes:

1.With no preoxygenation, the starting $\mathrm{SpO}_{2}$ dropped from $98 \%$ to $90 \%$ in 52 seconds with apnea. At the other extreme, following full preoxygenation with $100 \% \mathrm{O}_{2}$ for 3 minutes or more, $\mathrm{SpO}_{2}$ remained at $100 \%$ for 7.75 minutes during apnea and dropped to $90 \%$ after another 75 seconds. Hyperventilation did not result in more rapid normalization of $\mathrm{SpO}_{2}$, irrespective of the ventilation level (9).

2. Eighty-one patients $(20 \%)$ were extubated and discharged from the ICU in $48 \mathrm{~h}$ or less; these patients had higher pre-RSI $\mathrm{SpO}_{2}$ values (10).

3. A recent meta-analysis (11) conducted in 2017showed that apneic oxygenation was associated with decreased hypoxemia, first-pass intubation success, and increased lowest peri-intubation $\mathrm{SpO}_{2}$.

In conclusion, our study is a real-life experience emphasizing how a timely decision for intubation could have positive effects on intubation success without desaturating patients and could improve patient clinical outcomes. No matter how the increase of $\mathrm{SpO}_{2}$ is achieved before the ETI, it will contribute positively to the $\mathrm{O}_{2}$ reserve until the end of the ETI.
Abbreviations
ES - Emergency Service
EI - Endotracheal Intubation
ET - Endo tracheal tube
LMA — Laryngeal Mask Airway 
COPD - Chronic obstructive pulmonary disease

RSI — Rapid sequential intubation

IV - Intravenous

ARDS - Adult respiratory distress syndrome

$\mathrm{SAO}_{2}$ - Oxygen saturation

ETCO $_{2}$ - End tidal $\mathrm{CO} 2$ pital

IEAH - Istanbul Education and Research Hos-
PAO $_{2}$ - Partial Oxygen Pressure

$\mathrm{PACO}_{2}$ - Partial Carbondioxide Pressure

\section{Acknowledgment}

None.

Conflict of Interests: The authors declare that there are no conflicts of interest related to this article.

Funding: None

\section{Licensing}

This work is licensed under a Creative Commons Attribution 4.0 International (CC BY 4.0) License.

\title{
Sažetak
}

\section{UTICAJ BRZE INTUBACIJE NAARTERIJSKE KRVNE GASOVE TOKOM FAZE PREOKSIGENACIJE IZVRŠENE NA BOLNIČKOM ODELJENJU URGENTNE MEDICINE}

\author{
Suzer Ergun Neslihan, ${ }^{1}$ Sirkeci Ozgur, ${ }^{2}$ Sirkeci Erkus Emel ${ }^{3}$ \\ ${ }^{1}$ Kocaeli Gebze Fatih State Hospital Emergenceny Service, Kocaeli, Turkey \\ ${ }^{2}$ Suleyman Demirel University Faculty of Medicine İnternal Medicine Gastroenterology Department, Isparta, Turkey \\ ${ }^{3}$ Near East University Faculty of Medicine Emergency Department, Girne, Cyprus
}

Cilj: Tokom brze intubacije (RSI), rezerva $\mathrm{O}_{2}$ ograničava trajanje intubacije. Cilj studije bio je ispitati uticaj RSI na gasove arterijske krvi (ABG) tokom faze preoksigenacije.

Metode: Ova otvorena, prospektivna klinička studija ispitala je uzorke pacijenata koji su imali endotrahealnu intubaciju (ETI) kao RSI u periodu od marta 2014. do septembra 2014. godine u našoj hitnoj službi. Varijacije u ABG $\mathrm{PaO}_{2}$ i $\mathrm{PaCO}_{2}$ pre i posle preoksigenacije i nakon intubacije su ispitane i upoređene sa demografskim i kliničkim varijablama.

Rezultati: Studija je obuhvatila 67 pacijenata (46 muškaraca, 21 žena) sa prosečnom starošću od 69,9 godina. SBP, DBP i MABP su se smanjili, dok su se puls i $\mathrm{SpO}_{2}$ povećali. Nije primećena razlika između vrednosti $\mathrm{PaO}_{2}$ i demografskih i kliničkih varijabli; međutim, pronađena je statistički značajna veza između razlike (D) između vrednosti $\mathrm{PaO}_{2}$ izmerenih na-

\section{REFERENCES}

1. Vissers RJ, Danzl DF. Tracheal intubation and mechanical ventilation. In Tintinalli JE, Stapcyzynski JS, Cline DM, Ma OJ, Cydulka RK, Meckler GD (eds.). Tintinalli's Emergency Medicine: A comprehensive study guide, 7th edition, New York, Mc Graw-Hill, 2011, pp 198-209.

2. Weingart SD, Levitan RM. Preoxygenation and prevention of desaturation during emergency airway manage- kon endotrahealne trahealne intubacije (ETI) i nakon preoksigenacije i $\mathrm{ABG} \mathrm{SpO}_{2}$ i klasifikacije $\mathrm{SpO}_{2}$ pre preoksigenacije.

Zaključak: Odnos između $\mathrm{SpO}_{2}$ i njegove klasifikacije nakon ETI i povećanog $\mathrm{ABG} \mathrm{SpO}_{2}$ bio je statistički značajan. Naša studija iz stvarnog života naglašava da bi odlučivanje o intubaciji bez desaturacije pacijenata moglo imati pozitivne efekte na uspeh intubacije. Bez obzira na to, povećanje $\mathrm{SpO}_{2}$ pre ETI -a pozitivno će doprineti rezervi $\mathrm{O}_{2}$ do kraja ETI -a. Starost nije uticala na $\mathrm{DPaO}_{2}$, pre i posle preoksigenacije; pol; indeks telesne mase (BMI) i njegovu klasifikaciju; GCSS; vitalni znaci i nalazi ABG prikupljeni pre preoksigenacije; stopa disanja (RR) tokom preoksigenacije; trajanje preoksigenacije; upotreba vazdušnog prolaza ili curenje vazduha.

Ključne reči: Brza intubacija sekvenci, preoksigenacija, hitno odeljenje.

ment. Ann Emerg Med. 2012; 59(3): 165-75.e1. doi: 10.1016/j. annemergmed.2011.10.002.

3. Calvin A Brown CA, Sakles JC. Rapid sequence intubation in adults. Uptodate. www.uptodate.com/contents/rapid-sequence-intubation-in-adults.

4. Davis DP, Dunford JV, Poste JC, Ochs M, Holbrook T, Fortlage D, et al. The impact of hypoxia and hyperventilation on outcome after paramedic rapid sequence intubation of 
severely head-injured patients. J Trauma. 2004; 57(1): 1-8; discussion 8-10. doi: 10.1097/01.ta.0000135503.71684.c8.

5. Delay JM, Sebbane M, Jung B, Nocca D, Verzilli D, Pouzeratte $\mathrm{Y}$, et al. The effectiveness of noninvasive positive pressure ventilation to enhance preoxygenation in morbidly obese patients: a randomized controlled study. Anesth Analg. 2008; 107(5): 1707-13. doi: 10.1213/ane.0b013e318183909b.

6. Herriger A, Frascarolo P, Spahn DR, Magnusson L. The effect of positive airway pressure during pre-oxygenation and induction of anaesthesia upon duration of non-hypoxic apnoea. Anaesthesia. 2004; 59(3): 243-7. doi: 10.1111/j.13652044.2004.03615.x.

7. Hart D, Reardon R, Ward C, Miner J. Face mask ventilation: A comparison of three techniques. J Emerg Med. 2013; 44(5): 1028-33. doi: 10.1016/j.jemermed.2012.11.005.

8. Chroniere A, Girard F, Boudreault D, Ruel M, Girard DC. Voluntary hyperventilation before a rapid sequence induction of anesthesia does not decrease postintubation $\mathrm{PaCO} 2$.

\section{Correspondence to/Autor za korespondenciju}

Neslihan Ergün Süzer

Kocaeli Gebze State Hospital

Gebze/Kocaeli

Phone: +905064810683

Email: dr.neslihansuzer@gmail.com
Anesth Analg. 2001; 93(5): 1277-80. doi: 10.1097/00000539200111000-00050.

9. Lerant AA, Hester RL, Coleman TG, Phillips WJ, Orledge JD, Murray WB. Preventing and treating hypoxia: Using a physiology simulator to demonstrate the value of pre-oxygenation and the futility of hyperventilation. Int J Med Sci. 2015; 12(8): 625-32. doi: 10.7150/ijms.12077. eCollection 2015

10. Davis DP, Vadeboncoeur TF, Ochs M, Poste JC, Vilke GM, Hoyt DB.The association between field Glasgow Coma Scale score and outcome in patients undergoing paramedic rapid sequence intubation. J Emerg Med. 2005; 29(4): 391-7. doi: 10.1016/j.jemermed.2005.04.012.

11. Oliveira J E Silva L, Cabrera D, Barrionuevo P, Johnson RL, Erwin PJ, Murad MH, et al Effectiveness of apneic oxygenation during intubation: A systematic review and meta-analysis. Ann Emerg Med. 2017; 70(4): 483-94.e11. doi: 10.1016/j.annemergmed.2017.05.001. 